\title{
Geoelectric Tomography Study of Hydrocarbon Spill at IJEDODO Area, Abule Ado, Lagos
}

\author{
Adeoye-Oladapo O.O., Oladapo M. I.
}

\begin{abstract}
Geo-tomography study has been undertaken to determine the level of pollution occasioned by hydrocarbon spill at Ijedodo section of petroleum pipeline route at Ijedodo area of Abule Ado, Lagos. The field study involved the electrical resistivity tomography method using Dipole-Dipole electrode configuration. Traverse length of $1,870 \mathrm{~m}$ was occupied with electrode separations of $10 \mathrm{~m}$ and inter-dipole separation factor (n) varied from 1 to 8 . The study area is underlain by the Dahomey Sedimentary Basin. The data are presented as field and theoretical pseudosections alongside 2-D resistivity structure. 2-D Resistivity Structure output presents inversion of the field data to obtain a model utilized for subsurface characterization. Observed high resistivity values are attributable to resistive sand units while low values obtained are diagnostic of conductive clay units. However, anomalously high resistivity values recorded are attributable to hydrocarbon invasion of some pore spaces. Dipole-Dipole field and theoretical pseudosections generated for the segment show predominance of conductive (clay) materials interspersed with slightly resistive (sand) materials beneath the southern half $(1000 \mathrm{~m})$ of the investigated segment.

An isolated conductive feature (clay) was delineated beneath hydrocarbon pollution point. Finite Difference Method (FDM) inversion section of the investigated section however presents low resistivity materials (presumably clay) constituting the top segment within $180-970 \mathrm{~m}$ to depth of about $23 \mathrm{~m}$. The section presents anomalously high resistivity constituents (diagnostic of severe hydrocarbon impact) at the lower segment in areas around $390-940 \mathrm{~m}$ and $1740-1870 \mathrm{~m}$.
\end{abstract}

Index Terms - Geo-tomography, hydrocarbon spill, pseudosections, Finite Difference Method (FDM).

\section{INTRODUCTION}

Pipeline rupturing or vandalization has become a disturbing facet of the Nigeria oil industry. While rupturing may be attributable to system failure or inadvertent action, vandalization presents a deliberate attack on the pipelines with intent to siphon the fluid for pecuniary purposes. The environmental degradation associated with spillage from oil pipeline present devastating consequences. Damages to the environment may remain for a very long period thus rendering the groundwater contaminated and unsuitable for use. Ezeh et al., (2014) described pipeline system as a medium of transportation usually used for conveying very sensitive products such as crude oil, natural gas and industrial chemicals, in which unattended problems in their operation

1Adeoye-Oladapo O.O., Department of Physics, Adeyemi College of Education, Ondo, Nigeria.

Oladapo M.I., Department of Applied Geophysics, Federal University of Technology, Akure, Nigeria. results in unimaginable catastrophe. The economic, human and environmental consequences of oil spill are great (Rim-Rukeh, 2015). When oil spillage occurs, the beauty or the aesthetics of the ecology is damaged (Clinton et al., 2009). Oil introduced to the environment can elicit gross biological damage, physiological effects on the biota (both plants and animals) and a broad range of ecological changes (Briggs et al., 1996). Petroleum hydrocarbons can affect and cause changes in many organisms at all levels; cellular, organismic and ecosystems (Rim-Rukeh, 2015). Effects on marine organisms range across a spectrum from toxicity especially for light oils and products to smothering heavier oils and weathered residues (Rim-Rukeh, 2009). The presence of toxic components does not always cause mortality, but may induce temporary effects like narcosis and tainting of tissues, which usually subside over time. Other environmental impacts of oil spill may include: restriction of recreational use of such water bodies, non-availability of clean water for cooling purposes for industries located water bodies, and disruption of routine harbour activities such as ferry services (Osibanjo and Ajayi, 1989). In addition, when oil spills on surface of water bodies such as streams, rivers and lakes, it alters the quality of the water such that it makes it unfit for human consumption. It has been speculated that, one barrel of crude oil can make one million barrels of water undrinkable (Uzoekwe and Achudume 2011; Ordinioha and Sawyer 2010), disruption of fisheries activities (Rim-Rukeh, 2009), and most importantly oil spill have been reported to pose a significant potential for adverse human health effects (Getter et al., 1985). In tropical regions, mangrove swamps provide an extremely rich and diverse habitat as well as coastal protection and important nursery areas and in the event oil spill breathing roots of mangroves are smothered (NDES, 2003).

At the study area, a pipeline conveying refined petroleum products from the Lagos port on the southern flank to storage tanks located north of the metropolis has suffered several rupturing and vandalization thus resulting in oil spill and fire outbreaks. Makinde and Tologbonse (2016) undertook oil spill assessment in Ijedodo (area of study) using geospatial technique and observed a steady decline of $29.1 \%$ in vegetation due to negative effect of oil spill from the pipeline.

A deeper burial of the pipeline is therefore proposed to prevent the continual vandalization of the pipeline. However, a detailed subsurface stratification of the route needs be evolved to ensure incorporation of effective cathodic protection unit thus ensuring corrosion reduction. Electrical resistivity was adopted to evolve a tomography of the deeper pipeline route. In addition to the uses of tomography in 
geophysics, it also has applications in radiology, archaeology, biology, atmospheric science, oceanography, astrophysics, quantum information and in many other areas of science Electrical resistivity tomography has been successfully applied in geologic, hydrogeologic, environmental and engineering (Chambers et al., 2006). Electrical resistivity tomography has also been successfully deployed in subsurface solute transport (Kemna et al., 2002).

The aim of the electrical resistivity tomography study is to characterize and evolve the subsurface setting preparatory to deep pipeline construction.

The objectives of the investigation are;

i. To undertake geophysical data acquisition on the Ijedodo section of petroleum products pipeline.

ii. To analyse and interpret the results obtained in (i) above - in both qualitative and quantitative terms to establish the geo-electric/geologic layering within the segment;

iii. To delineate the geophysical features such as conductive (clay) and resistive (sand) bodies.

iv. To characterize and evolve the subsurface setting from the results of (i) - (iii) above.

\section{STUDY AREA DESCRIPTION}

Abule Ado where Ijedodo is located (Fig. 1) is situated on the western flank of Lagos metropolis off the Lagos-Badagry dual carriage way. The petroleum product pipeline route is oriented approximately NNE-SSW. Ijedodo is an evolving urban settlement located within the Ojo Local Government Area of Lagos. It is situated within Oto-Awori and Iba Local Community Development Area (LCDA). Other communities adjoining Ijedodo are Abule Ado and Ijegun.

\section{DESCRIPTION OF GEOLOGY AND GEOMORPHOLOGY OF LAGOS}

Lagos metropolis is located within the Western Nigeria Coastal Zone, a zone of coastal creeks and lagoons (Pugh 1954; Longe et al. 1987) developed by barrier beaches associated with sand deposition (Hill and Webb 1958). The study area - Ijedodo - falls entirely in the Dahomey Basin. The Dahomey Basin was formed following the break-up of the African and South American Plates (Burke et al 1971). The earliest sediments in the area were deposited as a result of the first major marine transgression in South Western Nigeria (Kogbe, 1974).

The upper sediments in the Dahomey Basin are recent. This is underlain by Coastal Plain Sands of the Quaternary Age. Basically the geologic sequence in the Dahomey Basin extends from Precambrian to Recent. Three distinct sequences, which are closely related to the geology of the sediments, are identified from past studies of southwestern Nigeria. Recent sediments generally occur as unconsolidated sands, clays and mud along the coastal areas. Figure 2 shows a section of the simplified geological map of Lagos metropolis, after Jones and Hockey, (1964) with the relative position of the study area indicated.

The Coastal Plain Sands otherwise known as the Benin formation was deposited during the Late Tertiary - Early Quaternary period. The formation outcrops in the northeast of the coastal belt and dips at low angle in the southwest (Offodile, 1992).

The Benin formation is composed of lenticular unconsolidated yellowish (ferruginous) to whitish sands with shale, clay and sandy clay intercalations (Jones and Hockey, 1964; Offodile, 1992). The sands are coarse, gravelly and locally fine grained, poorly to well sorted, sub-angular to well rounded and bears lignite streaks/wood fragments in places. 
World Journal of Innovative Research (WJIR)

ISSN: 2454-8236, Volume-6, Issue-5, May 2019 Pages 22-29

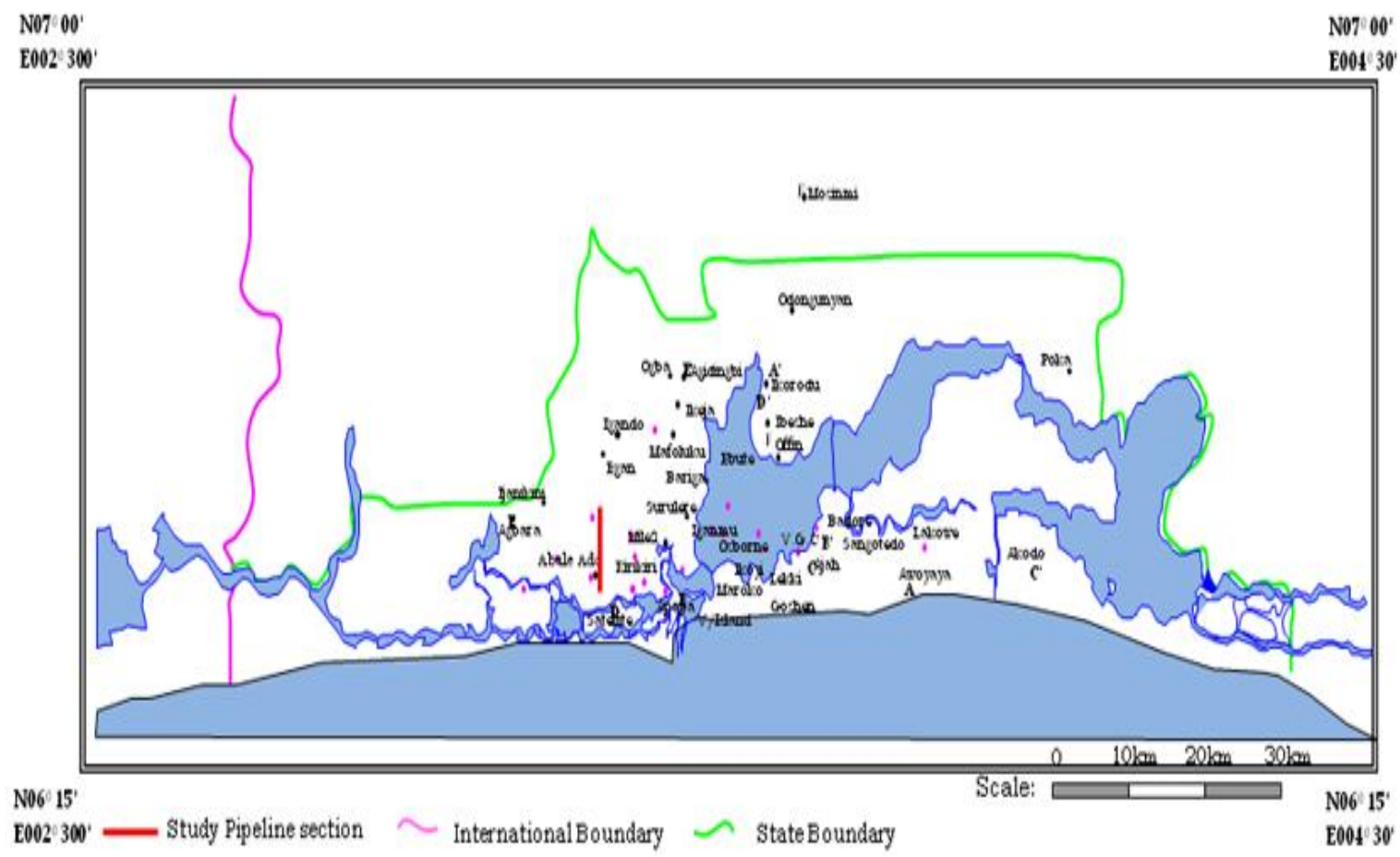

Fig. 1: Map of Lagos State showing location of ljedodo study section of NNPC pipeline at Abule Ado

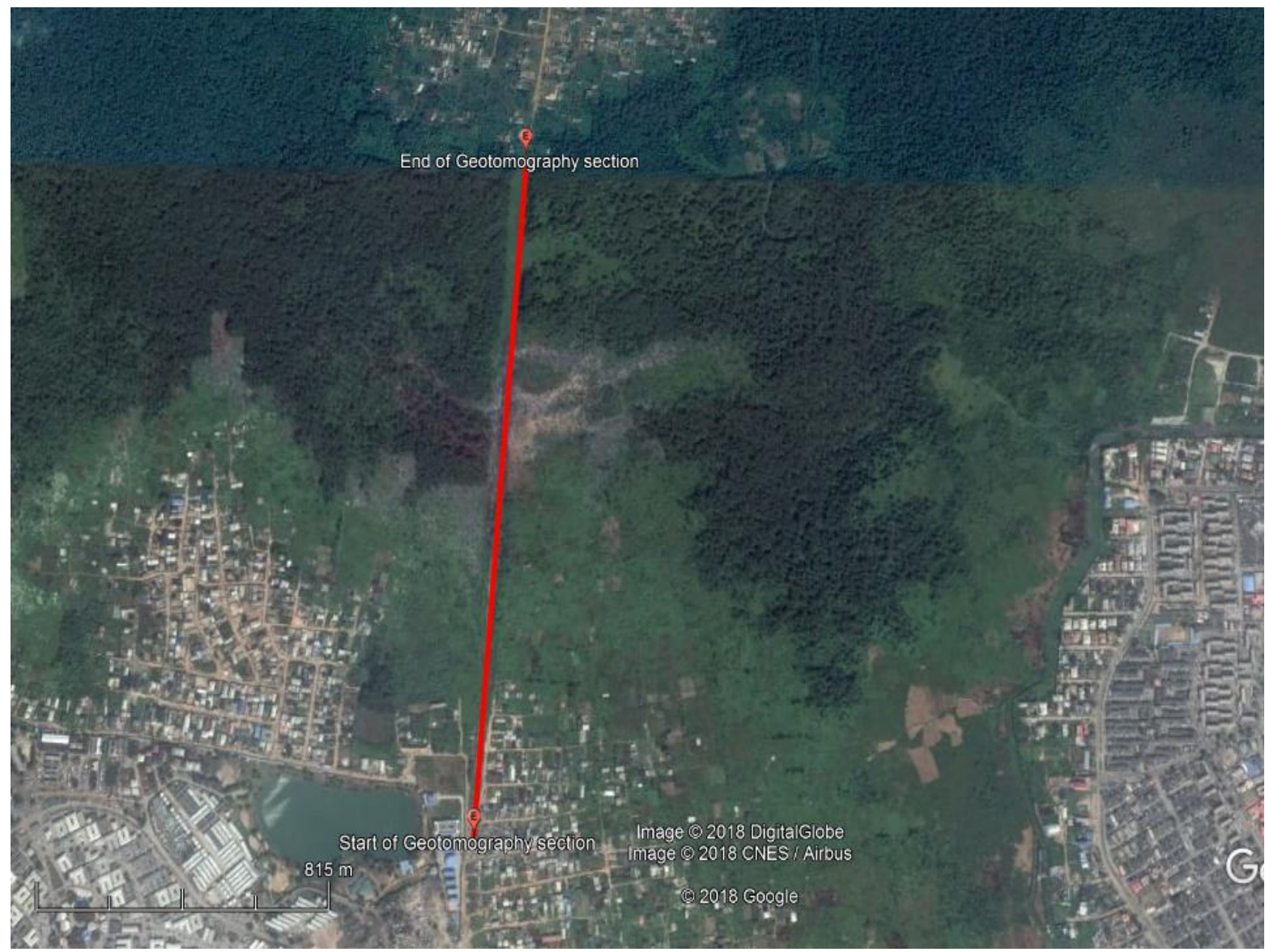

Fig. 2: Satellite Image Showing the location of Study Area 


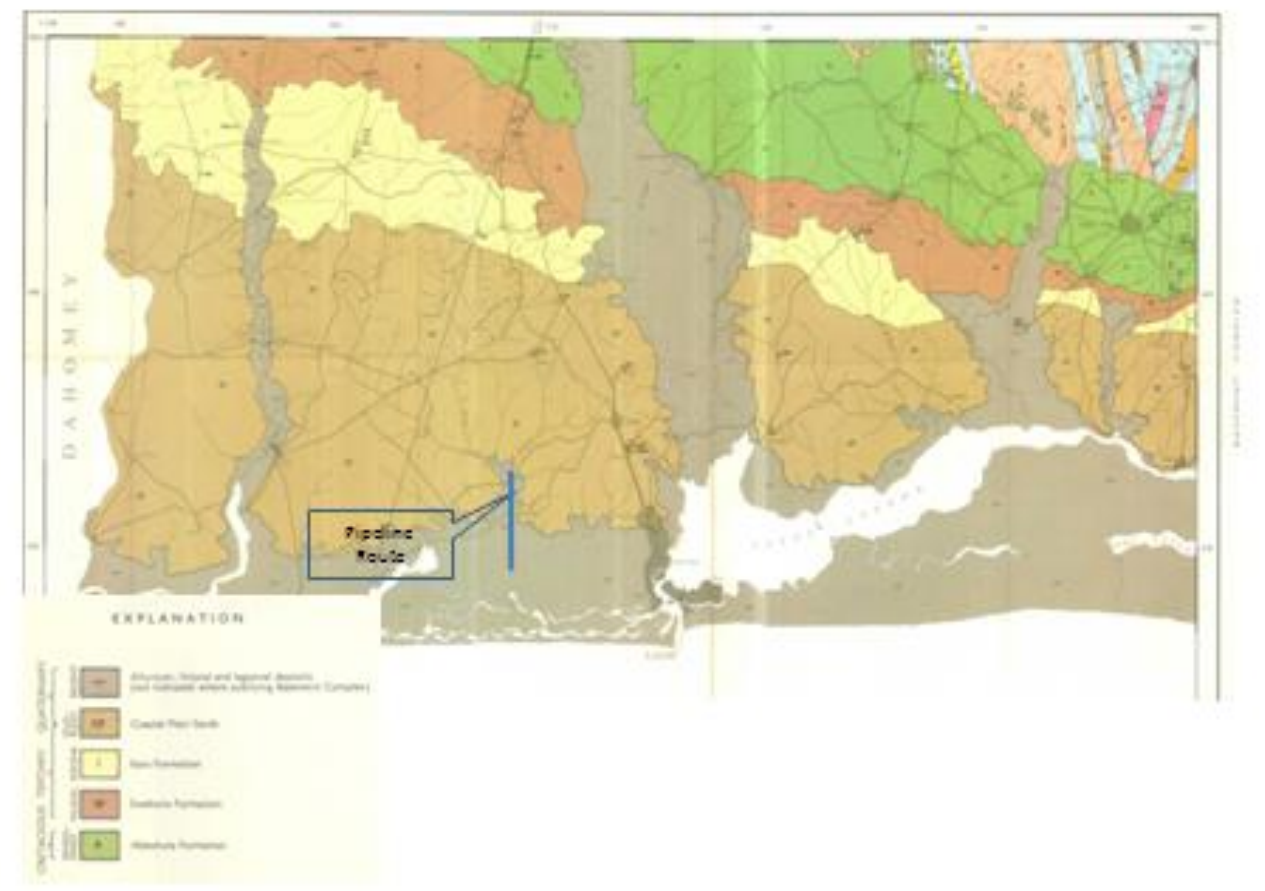

Fig. 3: Geological map of Lagos State (GSN, 1963) showing the location of pipeline route

Lagos is situated within Barrier-lagoon complex geomorphologic unit which extends eastward for about 200 $\mathrm{km}$ from the Nigeria/Benin Republic border to the western limit of the transgressive mud coast (FEPA, 1997). The morphology has largely been determined by coastal dynamics and drainage (Ibe, 1988). The Barrier-lagoon complex is backed by the Badagry Creek, the Lagos Lagoon, Lekki Lagoon and other numerous creeks.

Lagos is within a tropical climate consisting of rainy season (April to November) and dry season (December to March). The climatic characteristics of Lagos are governed by two air masses, the south westerly wind and the north east harmattan dry wind. Temperatures in Lagos are relatively high varying from $25.5^{\circ} \mathrm{C}$ to $30.5^{\circ} \mathrm{C}$ (Ibe et al, 1984).

\section{MATERIALS AND METHOD}

Qualitative resistivity studies on the pipeline route principally involved the Dipole-Dipole electrode array profiling along the existing pipeline route (Fig. 3). Dipole electrode separation of $10 \mathrm{~m}$ and expansion factor of 1 to 8 were undertaken on the traverse.

The Universal Transverse Mercator (UTM) system of coordinates was obtained using Garmin GPSMAP 60CSx.

For the field data acquisition works, ABEM SAS 1000 Resistivity Meter complete with peripherals were used for resistivity measurements. The 2-D electrical resistivity tomography survey was accomplished using Dipole-Dipole electrodes array that were laid out at $10 \mathrm{~m}$ spacing. Expansion factor of 1 to 8 was undertaken on the traverse.

The Dipole-Dipole array is a 2-D imaging technique that involves the measurement of lateral and vertical variations in apparent resistivity of the subsurface earth (Roy and Apparao, 1971). The apparent resistivity is calculated from the equation below,

$$
\rho_{a}=\frac{\Delta V}{I} \pi n a(n+1)(n+2)
$$

The $\Delta V / I=R$ (the ground resistance (ohms)) and spacing of the electrodes in each pair is $a(m)$. The measured resistivity values are plotted against the points of intersection of two $45^{\circ}$ inclined lines from the mid - points of the current and potential dipoles. The interpretation usually involves the construction of geoelectric sections and inversion into 2D resistivity images.

One Thousand Four Hundred and Sixty Four (1464) dipole-dipole data points were acquired using $10 \mathrm{~m}$ station interval on the pipeline traverse. In the field, the expansion factor, $n$ (distance between the leading potential and trailing current electrodes), was varied from 1 to 8 with a depth target of $50 \mathrm{~m}$.

The field resistivity data were processed using the DIPROfWIN 4.01 software developed by Dr. Jung Ho Kim of the Korea Institute of Mining and Geology (KIGAM). DIPROfWIN is a fully automated two and half-dimensional (2.5D) inversion routine based on a finite difference modeling (FDM) or finite element modeling (FEM) approximations to the calculation of model responses. The software inverts the data using the smoothness-constrained least-squares inversion algorithm to achieve stable results. The program uses the active constraint balancing (ACB) method which accounts for the use of variable Lagrangian multiplier at each of the parameterized blocks of the model during the inversion process to enhance both resolution and stability (Yi and Kim, 1998). The FDM inversion method was used to process data for this study.

The inversion algorithm first computes an initial model of subsurface resistivity distribution using the calculated apparent resistivity values and generates a response resistivity field based on the initial model, and then it computes and 
World Journal of Innovative Research (WJIR)

ISSN: 2454-8236, Volume-6, Issue-5, May 2019 Pages 22-29

iteratively minimizes the error between the synthetic and observed resistivity fields until a reasonable fit is achieved. Once the misfit is less than $5 \%$, the iteration is stopped and the result is output. The results displayed in the output window include the observed field pseudosection, the computed theoretical data pseudosection, and the inverted subsurface $2 \mathrm{D}$ resistivity structure.

The variation in topography along the pipeline at Ijedodo was not considered significant as to be used in the modeling process. The inverted $2 \mathrm{D}$ resistivity structure was used to delineate possible subsurface resistivity configuration.

\section{RESULTS}

The field data acquired are presented as Dipole-Dipole sections (Field Data Pseudosection, Theoretical Data Pseudosection and 2-D Resistivity Structure) (see Fig. 4). The interpretation results summaries are presented in Table 1.

TABLE

\section{1: 2D GEOELECTRIC TOMOGRAPHY DESCRIPTION TABLE}

\begin{tabular}{|c|c|c|c|c|}
\hline $\begin{array}{l}\text { Section }(\mathrm{m}) \\
\text { along pipeline } \\
\text { traverse }\end{array}$ & Depth (m) & Description & $\begin{array}{l}\text { Station Points along } \\
\text { pipeline traverse } \\
\text { (m) }\end{array}$ & Remarks \\
\hline \multirow[t]{3}{*}{$0-100$} & $0-20$ & Clayey Sand & & \\
\hline & $20-35$ & Sandy Clay & & \\
\hline & $35-50$ & Clay & & \\
\hline \multirow{5}{*}{$100-200$} & $0-20$ & Clayey Sand & & \\
\hline & \multirow[t]{2}{*}{$20-35$} & Sandy Clay & $100-140$ & \\
\hline & & Clayey Sand & $140-200$ & \\
\hline & \multirow[t]{2}{*}{$35-50$} & Clay & $100-130$ & \\
\hline & & Clayey Sand/Sand & $130-200$ & \\
\hline \multirow[t]{6}{*}{$200-300$} & \multirow[t]{2}{*}{$0-20$} & Clay@ the upper $10 \mathrm{~m}$ column & & \\
\hline & & Sandy Clay & & \\
\hline & \multirow{2}{*}{$20-35$} & Clayey Sand & $200-250$ & \\
\hline & & Clay & $250-300$ & \\
\hline & \multirow[t]{2}{*}{$35-50$} & Sand & $200-250$ & \\
\hline & & Clay & $250-300$ & \\
\hline \multirow[t]{4}{*}{$300-400$} & $0-20$ & Sandy Clay & & \\
\hline & $20-35$ & Sandy Clay & & \\
\hline & \multirow[t]{2}{*}{$35-50$} & Clay & $300-390$ & \\
\hline & & Sandy Clay & $390-400$ & \\
\hline \multirow[t]{3}{*}{$400-500$} & $0-20$ & Clay/Sandy Clay & & \\
\hline & $20-35$ & Sandy Clay/Clayey Sand & & \\
\hline & $35-50$ & Clayey Sand & & \\
\hline \multirow[t]{6}{*}{$500-600$} & $0-20$ & Clay/Sandy Clay & & \\
\hline & \multirow{2}{*}{$20-35$} & Clayey Sand & $500-530$ & \\
\hline & & Clay & $530-600$ & \\
\hline & \multirow[t]{3}{*}{$35-50$} & Clayey Sand & $500-530$ & \\
\hline & & Clay/Sandy Clay & $530-570$ & \\
\hline & & Clayey Sand & $570-600$ & \\
\hline \multirow[t]{5}{*}{$600-700$} & $0-20$ & Clay/Sandy Clay & & \\
\hline & \multirow[t]{2}{*}{$20-35$} & Sandy Clay & $600-670$ & \\
\hline & & Clay & $670-700$ & \\
\hline & \multirow[t]{2}{*}{$35-50$} & Clayey Sand & $600-670$ & \\
\hline & & Sandy Clay & $670-700$ & \\
\hline \multirow[t]{3}{*}{$700-800$} & $0-20$ & Clay & & \\
\hline & $20-35$ & Clay & & \\
\hline & $35-50$ & Sandy Clay/Clayey Sand & & \\
\hline \multirow[t]{5}{*}{$800-900$} & \multirow[t]{3}{*}{$0-20$} & Clay & $800-860$ & \\
\hline & & Sandy Clay & $860-880$ & \\
\hline & & Clay & $880-900$ & \\
\hline & $20-35$ & Clay/Sandy Clay & & \\
\hline & $35-50$ & Clayey Sand & & \\
\hline
\end{tabular}


TABLE 1 CONT'D: 2D GEOELECTRIC TOMOGRAPHY DESCRIPTION

\begin{tabular}{|c|c|c|c|c|}
\hline $\begin{array}{l}\text { Section }(\mathrm{m}) \\
\text { along pipeline } \\
\text { traverse }\end{array}$ & Depth (m) & Description & $\begin{array}{l}\text { Station Points } \\
\text { along pipeline } \\
\text { traverse }(\mathrm{m})\end{array}$ & Remarks \\
\hline \multirow[t]{7}{*}{$900-1000$} & $0-20$ & Clay & & \\
\hline & \multirow[t]{3}{*}{$20-35$} & Sandy Clay & $900-950$ & \\
\hline & & Clay & $950-990$ & \\
\hline & & Hydrocarbon Impact & $990-1000$ & \\
\hline & \multirow[t]{3}{*}{$35-50$} & Clayey Sand & $900-950$ & \\
\hline & & Clay & $950-980$ & \\
\hline & & Hydrocarbon Impact & $980-1000$ & \\
\hline \multirow[t]{3}{*}{$1000-1100$} & $0-20$ & Severe Hydrocarbon Impact & & \multirow{3}{*}{$\begin{array}{l}\text { Prevalence of } \\
\text { very high } \\
\text { resistivity }\end{array}$} \\
\hline & $20-35$ & Severe Hydrocarbon Impact & & \\
\hline & $35-50$ & Severe Hydrocarbon Impact & & \\
\hline \multirow{6}{*}{$1100-1200$} & \multirow[t]{2}{*}{$0-20$} & Clay/Sandy Clay & $1100-1150$ & \\
\hline & & Clayey Sand & $1150-1200$ & \\
\hline & \multirow[t]{2}{*}{$20-35$} & Clay/Sandy Clay & $1100-1150$ & \\
\hline & & Clayey Sand & $1150-1200$ & \\
\hline & \multirow[t]{2}{*}{$35-50$} & Clay & $1100-1170$ & \\
\hline & & Clayey Sand & $1170-1200$ & \\
\hline \multirow{3}{*}{$1200-1300$} & $0-20$ & Severe Hydrocarbon Impact & & \multirow{12}{*}{$\begin{array}{l}\text { Characterized } \\
\text { by very high } \\
\text { resistivity } \\
\text { values }\end{array}$} \\
\hline & $20-35$ & Severe Hydrocarbon Impact & & \\
\hline & $35-50$ & Severe Hydrocarbon Impact & & \\
\hline \multirow[t]{3}{*}{$1300-1400$} & $0-20$ & Severe Hydrocarbon Impact & & \\
\hline & $20-35$ & Severe Hydrocarbon Impact & & \\
\hline & $35-50$ & Severe Hydrocarbon Impact & & \\
\hline \multirow[t]{3}{*}{$1400-1500$} & $0-20$ & Severe Hydrocarbon Impact & & \\
\hline & $20-35$ & Severe Hydrocarbon Impact & & \\
\hline & $35-50$ & Severe Hydrocarbon Impact & & \\
\hline \multirow[t]{3}{*}{$1500-1600$} & $0-20$ & Severe Hydrocarbon Impact & & \\
\hline & $20-35$ & Severe Hydrocarbon Impact & & \\
\hline & $35-50$ & Severe Hydrocarbon Impact & & \\
\hline \multirow[t]{6}{*}{$1600-1700$} & \multirow[t]{2}{*}{$0-20$} & Hydrocarbon Impact & $1600-1610$ & \\
\hline & & Clay & $1610-1700$ & \\
\hline & \multirow[t]{2}{*}{$20-35$} & Hydrocarbon Impact & $1600-1650$ & \\
\hline & & Clay & $1650-1700$ & \\
\hline & \multirow[t]{2}{*}{$35-50$} & Hydrocarbon Impact & $1600-1650$ & \\
\hline & & Clay & $1650-1700$ & \\
\hline \multirow[t]{5}{*}{$1700-1800$} & $0-20$ & Clay/Sandy Clay & & \\
\hline & \multirow[t]{3}{*}{$20-35$} & Clay/Sandy Clay & $1700-1740$ & \\
\hline & & Sandy Clay & $1740-1760$ & \\
\hline & & Clay & $1760-1800$ & \\
\hline & $35-50$ & Sandy Clay/Clayey Sand & & \\
\hline \multirow[t]{3}{*}{$1800-1870$} & $0-20$ & Clay/Sandy Clay & & \\
\hline & $20-35$ & Clay & & \\
\hline & $35-50$ & Sandy Clay/Clayey Sand & & \\
\hline
\end{tabular}

Table 2: Guide to Geoelectric 2D Section lithology delineation

\begin{tabular}{|l|l|}
\hline Range of Resistivity Values $(\Omega-\mathrm{m})$ & Lithology (Sedimentary) \\
\hline$<50$ & Clay \\
\hline $51-400$ & Sandy Clay \\
\hline $401-855$ & Clayey Sand \\
\hline $856-1200$ & Sand \\
\hline$>1200$ & Hydrocarbon Impact \\
\hline
\end{tabular}




\section{World Journal of Innovative Research (WJIR) ISSN: 2454-8236, Volume-6, Issue-5, May 2019 Pages 22-29}

\section{RESULTS AND DISCUSSION}

The Dipole-Dipole data are presented as Field Data Pseudosection, Theoretical Data Pseudosection and 2-D Resistivity Structure. The Field data pseudosection presents the contour of apparent resistivity values obtained on the field. The section shows the prevalence of low resistivity values in the field readings except in some isolated cases of high resistivity values attributable to hydrocarbon spill which was observed along the pipeline route.

The theoretical section presents filtered data with expected level of correlation with the plotted raw field data. Where satisfactory correlation is not achieved, additional iterations are undertaken until a satisfactory.

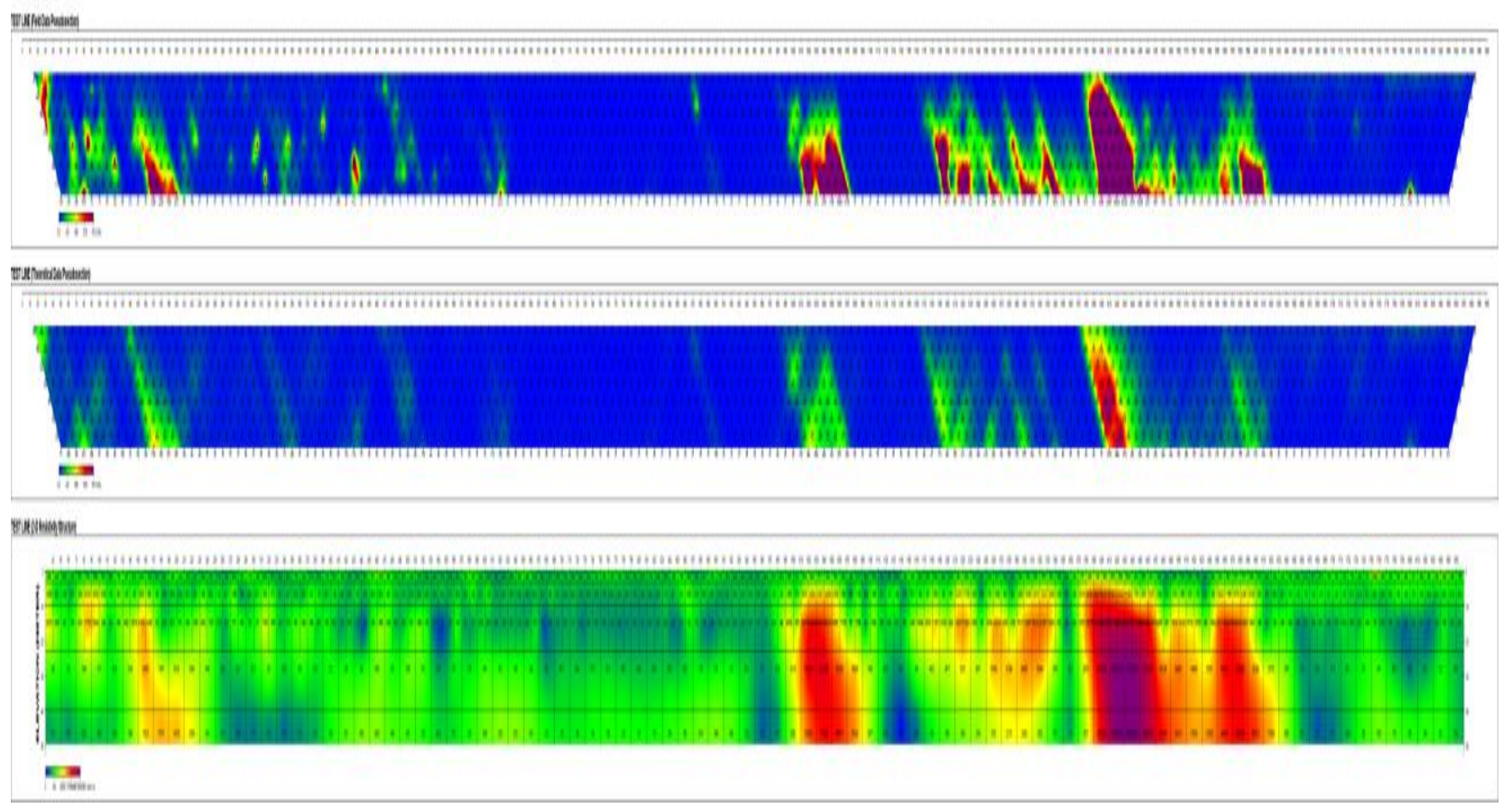

Fig. 4: Field Data and Theoretical Data Pseudosections and 2-D Resistivity Structure obtained at the Study Area

correlation is achieved. However, the level of correlation achieved in 10 times iteration is high and thus considered sufficient.

The 2-D Resistivity Structure present inversion of the field data to obtain a subsurface model that was utilized for subsurface characterization. Low resistivity values obtained in the study are presumably due to conductive clay units while high resistivity values are indicative of resistive sand units. However, anomalously high resistivity values recorded are attributable to hydrocarbon invasion of some pore spaces.

\section{CONCLUSIONS}

The geophysical field study along the Ijedodo segment of the petroleum products supply pipeline at Ijedodo in Lagos indicate that clayey and muddy materials constitute the top segment within $180 \mathrm{~m}-970 \mathrm{~m}$ to depth of about $23 \mathrm{~m}$. At the lower segment in areas around $390-940 \mathrm{~m}$ and $1740-1870$ $\mathrm{m}$ the section presents relatively high resistivity constituents diagnostic of sandy clay/clayey sand.

Clayey materials constituents underlying the pipeline route to depth range of $2-20 \mathrm{~m}$ while sandy clay/silt are the major constituents within $20-35 \mathrm{~m}$. Clayey sand/sand will be encountered if the pipeline is routed through depth range of $35-50 \mathrm{~m}$. It should however be noted that groundwater level is generally shallow in the area.

\section{REFERENCES}

[1] Briggs, K.T., Yoshida, S.H. and Gershwin, M.E. (1996). The Influence of Petrochemicals and Stress on the Immune System of Seabirds. Regulatory Toxicology and Pharmacology, 23, 145-155. http://dx.doi.org/10.1006/rtph.1996.0036

[2] Burke, K., Dessauvagie, T.F.J. and Whiteman, A.J. (1971). Opening of the Gulf of Guinea and geological history of the Benue depression and Niger delta. Nature Phys. Sci. 233, p. 51-55.

[3] Chambers, J.E. Kuras, O., Meldrum, P.I., Ogilvy, R.D. and Hollands, J. (2006) Electrical resistivity tomography applied to geologic, hydrogeologic, and engineering investigations at a former waste-disposal site. Geophysics Vol. 71, 6 IND-Z126 https://doi.org/10.1190/1.2360184

[4] Clinton, H.I., Ujagwung, G.U. and Horsfall, M. (2009) Evaluation of Total Hydrocarbon Levels in Some Aquatic Media in Oil Polluted Mangrove Wetland in the Niger Delta. Applied Ecology and Environmental Research, $\quad 7, \quad 111-\quad 120$. http://dx.doi.org/10.15666/aeer/0702_111120

[5] Ezeh, G.N., Chukwuchekwa , N., Ojiaku, J .C. and Ekeanyawu, E. (2014). Pipeline Vandalization Detection Alert with Sms. Journal of Engineering Research and Applications Vol. 4, Issue 4 (Version 9), pp.21-25

[6] Federal Environmental Protection Agency (FEPA), 1997. Report on Coastal Profile of Nigeria. Large Marine Ecosystem Project for the Gulf of Guinea Submitted to Center for Environment and Development in Africa. 
[7] Getter, C.D., Ballou, T.G. and Koons, C.B. (1985) Effects of Dispersed Oil on Mangroves: Synthesis of a Seven-Year Study. Marine Pollution Bulletin, 16, 318-324. http://dx.doi.org/10.1016/0025-326X(85)90447-3

[8] Ibe AC (1988): Coastline erosion in Nigeria. Ibadan University Press, Ibadan, Nigeria 217p.

[9] Ibe AC, Awosika LF, Antia EE (1984): Progress report No. 2, Coastal Erosion Research Project NIOMR Special Pub. 106p.

[10] Jones, H.A. and Hockey, R.D. (1964) The Geology of Part of Southwestern Nigeria Geol. Surv. Nigeria, Bull, 31, $101 \mathrm{p}$.

[11] Kemna, A., Vanderborght, J., Kulessa, B., and Vereecken H. (2002). Imaging and characterisation of subsurface solute transport using electrical resistivity tomography (ERT) and equivalent transport models. Journal of Hydrology Volume 267, Issues 3-4, 15 Pages 125-146

[12] Kogbe CA (1974) The Upper cretaceous Abeokuta formation of south west Nigeria. Nigerian Field 39: 4.

[13] Longe EO, Malomo S, Olorunniwo MA (1987). Hydrogeology of Lagos Metropolis. Africa Journal of Earth Sciences., 6 (2), 163 - 174.

[14] Makinde, E.O. and Tologbonse, A.S. (2016). Oil Spill Assessment in Ijeododo Area of Lagos State, Nigeria Using Geospatial Techniques. Ethiopian Journal of Environmental Studies \& Management 10(4): 427 - 442, doi: https://dx.doi.org/10.4314/ejesm.v10i4.1

[15] NDES, Niger Delta Environmental Survey (2003) Phase 1: Report on the Niger Delta Environment

[16] Offodile, M. E. 1992. An approach to ground water study and development in Nigeria. Mecon, Jos, Nigeria, 247 pp

[17] Ordinioha, B. and Sawyer, W. (2010) Acute Health Effects of a Crude Oil Spill in a Rural Community in Bayelsa State, Nigeria. Nigerian Journal of Medicine, $19, \quad 140-144$ http://dx.doi.org/10.4314/njm.v19i2.56500

[18] Osibanjo, O. and Ajayi, S.O. (1981) Pollution Studies on Nigeria Rivers II, Water Quality of Some Nigeria Rivers. Environmental Research Series B, 2, 87-95.

[19] Pugh J.C. (1954). A classification of the Nigerian coastline. Journal of the West African Science Association. Vol. 1 pp 3-12.

[20] Rim-Rukeh, A. (2009). Environmental Science: An Introduction. Kraft Books, Ibadan.

[21] Rim-Rukeh, A. (2015). Oil Spill Management in Nigeria: SWOT Analysis of the Joint Investigation Visit (JIV) Process. Journal of Environmental Protection, 6, 259-271. http://dx.doi.org/10.4236/jep.

[22] Roy, A., Apparao, A. [1971] Depth of investigation in direct current methods. Geophysics, 36, 943-959.

[23] Uzoekwe, S.A. and Achudume, A.C. (2011) Pollution Status and Effect of Crude Oil Spillage in Ughoton Stream Ecosystem in Niger Delta. Journal of Ecology and The Natural Environment, 3, 469-473. http://dx.doi.org/10.5897/JENE11.071

[24] Webb J. E. and Hill M. B. (1958). Ecology of Lagos lagoons (II) The topography and physical features of Lagos harbour \& Lagos lagoons. Philosophical Transaction of Royal Society, London, B24, 319-333

[25] Yi, M. J. and Kim, J. H. (1998) "Enhancing the resolving power of the least squares inversion with active constraint balancing," in SEG Expanded Abstracts, 68 Annual Meeting, pp. 485-488, New Orleans, Fla, USA. 